\title{
Selecting and Testing Cryptogam Species for Use in Wetland Delineation in Alaska
}

\author{
ROBERT W. LICHVAR, ${ }^{1,2}$ GARY A. LAURSEN, ${ }^{3}$ RODNEY D. SEPPELT ${ }^{4}$ and WALTER R. OCHS ${ }^{1}$
}

\author{
(Received 31 March 2008; accepted in revised form 8 September 2008)
}

\begin{abstract}
To support the determination of hydrophytic vegetation in wetland delineations in Alaska, USA, a series of tests were conducted to develop a group of "test positive" species to be used in a "cryptogam indicator." In 2004, non-vascular cryptogam species (bryophytes, lichens, and fungi) from Interior and South-Central Alaska in the vicinities of Fairbanks and Anchorage were collected at a series of ten $50 \times 50 \mathrm{~cm}$ plots along two $30 \mathrm{~m}$ transects in each of six upland and five wetland sites. Nineteen moss and liverwort species were selected from 86 species surveyed to test for wetland fidelity. In 2005, a plot-based analysis of frequency and cover data yielded a revised list of 17 bryophyte species that were specific to wetland communities dominated by black spruce, Picea mariana (P. Mill.) B.S.P. Fungi and lichens were found to be inadequate wetland indicators in the sampled locations because the lichen species were sparsely distributed and the fungi were too ephemeral. The cryptogam indicator was thus restricted to bryophytes. Also in 2005, bryophytes were analyzed for their presence on microtopographic positions within the landscape, including tops of hummocks and hollows at the bases of hummocks. Upland bryophyte species were found on hummock tops inside the wetland boundary, but were not abundant in the hollows $(p<0.05)$. The fidelity of the species selected for use in the cryptogam indicator was tested. It was determined that if more than $50 \%$ of all bryophyte cover present in hollows is composed of one or more of the 17 wetland bryophytes tested in 2005, then vascular vegetation can be considered to be hydrophytic $(p<0.001)$.
\end{abstract}

Key words: Alaska, wetlands, delineation, bryophytes, indicators, mosses, Alaskan wetland supplement, mushrooms, lichens, cryptograms

RÉSUMÉ. Afin d'étayer la présence de végétation hydrophytique dans les délimitations de zones humides de l'Alaska, aux États-Unis, une série de tests a été effectuée dans le but d'aboutir à un groupe d'espèces « de test positives » à utiliser avec un « indicateur de sporophyte ». En 2004, des espèces de sporophytes non vasculaires (bryophytes, lichens et champignons) de l'intérieur et du centre-sud de l'Alaska, aux environs de Fairbanks et d'Anchorage, ont été recueillies à une série de dix parcelles de 50 sur $50 \mathrm{~cm}$ le long de deux transects de $30 \mathrm{~m}$ dans chacun de six sites montagnards et de cinq sites humides. Dix-neuf espèces de mousse et d'hépatiques ont été choisies à partir de 86 espèces prélevées dans le but d'en déterminer la fidélité aux zones humides. En 2005, une analyse de fréquence de parcelles et des données de couverture ont permis d'obtenir la liste révisée de 17 espèces de bryophytes propres aux zones humides dominées par l'épinette noire, Picea mariana (P. Mill.) B.S.P. Nous avons constaté que les champignons et les lichens étaient des indicateurs de zones humides inadéquats aux sites échantillonnés parce que les espèces de lichen étaient réparties maigrement et que les champignons étaient trop éphémères. Par conséquent, l'indicateur de sporophytes a été restreint aux bryophytes. Également en 2005, nous avons analysé les bryophytes afin d'en déterminer la présence à des positions microtopographiques du paysage, ce qui comprenait le sommet de hummocks et les creux à la base de hummocks. Des espèces de bryophytes montagnardes ont été décelées aux sommets de hummocks à l'intérieur de la limite des zones humides, mais celles-ci n'abondaient pas dans les creux $(p<0.05)$. La fidélité des espèces choisies afin d'être utilisées dans l'indicateur de sporophytes a été testée. Nous avons déterminé que si plus de $50 \%$ de toute la couverture de bryophyte présente dans les creux est composée de l'une ou plusieurs des 17 bryophytes de zones humides testées en 2005, la végétation vasculaire peut alors être considérée comme hydrophytique $(p<0,001)$.

Mots clés : Alaska, zones humides, délimitation, bryophytes, indicateurs, mousses, " Alaskan wetland supplement ", champignons, lichens, cryptogrammes

Traduit pour la revue Arctic par Nicole Giguère.

\footnotetext{
${ }^{1}$ U.S. Army Cold Regions Research and Engineering Laboratory, Hanover, New Hampshire 03755, USA

${ }^{2}$ Corresponding author: Robert.w.lichvar@usace.army.mil

${ }^{3}$ High Latitude Mycological Research Institute, 682 Lancaster Drive, Fairbanks, Alaska 99712, USA

${ }^{4}$ Australian Antarctic Division, Kingston 7050, Tasmania, Australia

(C) The Arctic Institute of North America
} 


\section{INTRODUCTION}

The U.S. Army Corps of Engineers Wetlands Delineation Manual (Environmental Laboratory, 1987), hereafter referred to as the 1987 Manual, uses three factors - hydrology, soils, and vegetation - to determine whether wetland conditions are present at any given site. To be considered a jurisdictional wetland under Sec. 404 of the Clean Water Act, a site must meet the criteria for all three parameters. For each factor, a series of field indicators is used as evidence to support particular criteria. In the case of vegetation, vascular plant species have been assigned wetland ratings corresponding to their frequency of occurrence in wetlands: Obligate (OBL) species occur at least $99 \%$ of the time in wetlands; Facultative Wetland (FACW) species, 67-99\%; Facultative (FAC) species, 34-66\%; Facultative Upland (FACU) species, 1-33\%; and Upland (UPL) species, less than $1 \%$ (Reed, 1988). To meet the hydrophytic vegetation criterion at a particular site, estimated areal cover values for the vascular plants are used along with their wetland plant indicator status to determine whether or not the dominant plant species are hydrophytes. The basic rule for meeting the hydrophytic vegetation criterion is that more than $50 \%$ of the dominant vegetation must be rated as hydrophytic. Species rated as FAC, FACW, and OBL are considered hydrophytic. When the vascular vegetation fails the indicator test, the site is considered to have upland vegetation. In some instances, particularly in Alaska, using existing field indicators to determine whether or not the vegetation is hydrophytic can be problematic.

Regional working groups assign wetland plant indicator status ratings across ten broad regions that typically include multiple states (Tiner, 2006). The database supporting the National Wetland Plant List (U.S. Army Corps of Engineers, 2009) used by each regional working group lacks frequency data for most species. But frequencies of wetland species are well documented in the literature and by direct reports from expert field delineators and botanists working with wetland species in these regions. This reference information, along with the expertise of the working groups and input from others, is used to assign wetland indicator ratings for each species within a region. However, the resulting lists of species known to occur in wetlands do not assign wetland indicator status ratings to localized subregions or particular vegetation communities; they do not address variations in species habitat preferences or environmental settings; and they contain no standardized method of testing the accuracy of the assigned ratings for problematic species.

In Alaska, $60 \%$ of the vascular flora is rated as hydrophytic (Tiner, 2006). Hydrophytic vegetation determinations are therefore problematic because certain groups of widespread wetland plants occur in both wetlands and uplands, and the indicator status ratings used across the entire region are inadequate to capture differences in ecological distribution patterns. For example, species such as paper birch (Betula papyrifera Marsh) are rated as FACU species. But in some wetland types, Betula is the dominant genus in the stand. These cases represent locations where FACU species are expressing their ability to be hydrophytes $33 \%$ of the time (Tiner, 1991). FACU communities fail the hydrophytic vegetation criterion, but are problematic for wetland delineation if hydric soils and hydrology indicators are present. In contrast, black spruce Picea mariana (P. Mill.) B.S.P., an FACW species, is widespread throughout Interior and South-Central Alaska and is one of the most frequently delineated wetland vegetation types in Alaska (U.S. Army Corps of Engineers, 2006).

The lack of accuracy in locating the hydrophytic portions within the black spruce communities is, in part, an unintended but inherent aspect of the methods used in assigning wetland plant indicator status. Since wetland indicator status ratings are assigned over large regions and frequency data for calibrating the ratings are typically lacking, regional wetland plant indicator status committees rely on literature, best professional judgment, and input from other regional experts. To address species with highly variable habitat preferences for both wetlands and uplands, the committees use broader indicator status group ratings such as FAC (species that occur in wetlands $34-66 \%$ of the time) to address many of these less specialized wetland species. As with certain black spruce communities and their associated species, these broader wetland indicator status groups do not bring clarity in identifying what portions of the community have wetland or upland vegetation. In contrast, a cryptogam indicator associated with black spruce communities that is being developed and tested brings the needed ability to determine the hydrophytic portions of both the vascular and cryptogam aspects of the community.

Non-vascular cryptogams reproduce sexually by producing spores. They include bryophytes (mosses, liverworts, and hornworts), fungi, and lichens. Cryptogams occur in all regions of the world and play an important role in a wide variety of ecosystem types (Slack, 1988; Berglund and Jonsson, 2001; Gignac, 2001). Usually, cryptogams reach their highest level of abundance and diversity in regions that have low evapotranspiration as a result of cooler temperatures and adequate precipitation (Vitt et al., 1988; Vellak et al., 2003; Gignac and Dale, 2005). In the United States, cryptogam species are common in the Arctic and boreal North, the Pacific Northwest, the upper Midwest, and northern New England where suitable climatic conditions prevail (Walker, 1995; Longton, 1997; Bedford and Godwin, 2003). Most regions of Alaska have a high abundance of cryptogams (Viereck et al., 1983; Ford and Bedford, 1987). In regions where cryptogam species make up a conspicuous part of the flora, they are usually included in ecological studies (Pharo and Beattie, 1997; Gignac and Dale, 2005; Locky et al., 2005; Muukkonen et al., 2006). However, wetland delineation in the United States, under Sec. 404 of the Clean Water Act, has to date included only vascular macrophytic plant species as indicators of hydrophytic vegetation.

Cryptogam species range from generalists to specialists in terms of habitat preferences (McCune and Geiser, 1997; 
Birks et al., 1998; Mills and Macdonald, 2004). While many species are known to be aquatic, others are limited to substrates that include rock, wood, dung, old bone, or other specialized habitats (Vitt et al., 1988; Kershaw, 1995). Mosses and lichens are dominant components of the understory of black spruce (Viereck et al., 1983; Locky et al., 2005). Species occurrences sort along gradients of environmental variables such as moisture, free water availability, shade, $\mathrm{pH}$, and soil mineral content (Vitt and Slack, 1984; Robinson et al., 1989; Gignac et al., 1991).

As part of the effort to update and regionalize the 1987 Manual in Alaska, the Alaskan Vegetation Working Group (2005) developed a cryptogam indicator through a series of studies undertaken during 2004 and 2005 in several black spruce community types in the Anchorage (South-Central Alaska) and Fairbanks (Interior Alaska) areas. The aim of these studies was to develop a group of highly reliable cryptogam species that could be used as a wetland indicator. The Alaskan Vegetation Working Group (2005) proposed the following cryptogam indicator formula to meet the hydrophytic vegetation criterion for problematic black spruce communities:

$$
\text { Cryptogam Indicator }=\frac{\text { wetland cryptogam cover }}{\text { total cryptogam cover }} \times 100 \%
$$

where wetland cryptogam cover is the sum of the cover of selected wetland cryptogams and total cryptogam cover is the sum of all cryptogam cover. Hydrophytic vegetation is present if the cryptogam indicator is $50 \%$ or greater.

In this paper, we describe tests conducted to develop a list of cryptogam species with high fidelity to black spruce wetlands in the Anchorage and Fairbanks areas for use in developing a hydrophytic vegetation indicator for wetland delineation purposes.

\section{MATERIALS AND METHODS}

\section{Study Region}

Two types of field sites were selected for this study. The first included several problematic areas selected to be surveyed for developing a list of candidate species for further testing. The second was a hydrologically monitored site used to test the candidate species for wetland fidelity and then make final species selections for use in the cryptogam indicator. In 2004, we surveyed a series of black spruce communities, including bogs, fens, and blanket bogs located in the vicinities of Anchorage and Fairbanks, Alaska (Fig. 1). These sites were suggested by local wetland delineators in the Anchorage and Fairbanks regions who identified problematic conditions confronting them in their regions. Most of these problematic sites were blanket bogs; they were located on or adjacent to gentle slopes near black spruce swamps, bogs, or fens that included parts of a wetland and adjacent uplands, as identified by the 1987

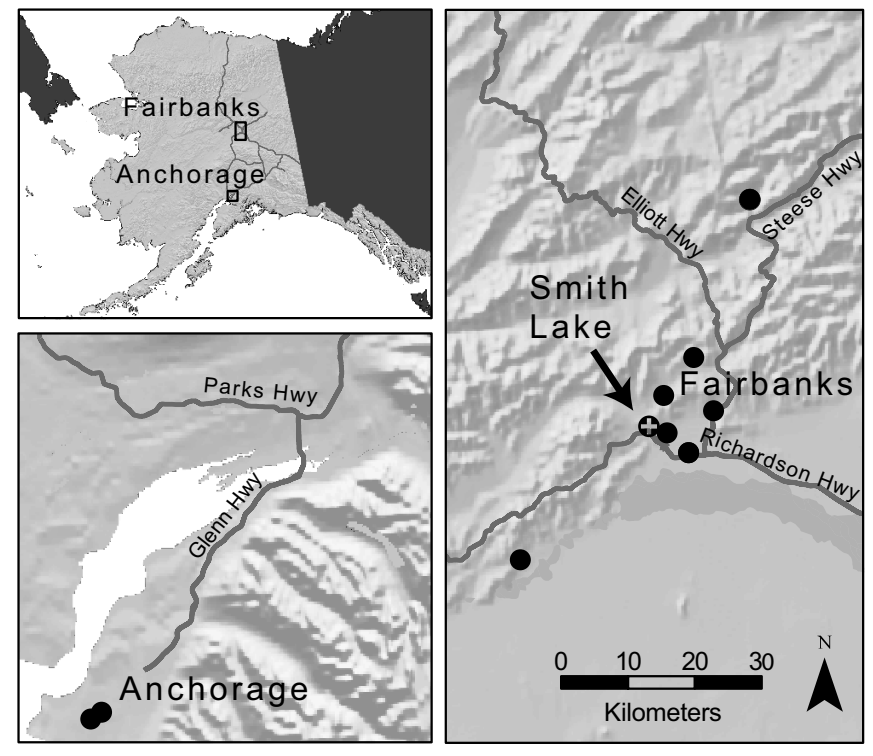

FIG. 1. Map of Alaska showing study areas near Anchorage and Fairbanks. Black dots on Anchorage and Fairbanks area maps $(\bullet)$ indicate site locations. See Table 1 for site descriptions.

Manual. To contrast cryptogam occurrences in problematic black spruce areas, we included five wetland and six upland sites. The upland sites lacked hydric soils and hydrology indicators. The 11 sites surveyed in 2004 included nine near Fairbanks and two in Anchorage (Table 1, Fig. 1).

The University of Alaska Fairbanks (UAF) maintains a hydrologically monitored site in a black spruce community at Smith Lake to evaluate permafrost influences on nearsurface hydrology, soils, and forest conditions (Zhu, 2004). In 2005 , we used this site to test the wetland cryptogam indicator and to verify the fidelity of the pre-selected wetland cryptogams from the 2004 list of species surveyed at the Anchorage and Fairbanks sites. Monitored data at the Smith Lake site included daily ground soil moisture readings from three locations along a gradient that included upland, wetland boundary, and wetland, as identified by the 1987 Manual.

\section{Field Surveys}

Initial field samplings of cryptogams were made at the 11 black spruce forest, blanket bog, and swamp locations selected by local delineators in the Anchorage and Fairbanks areas in 2004 (Table 1, Fig. 1). At each site, the 1987 Manual was used to identify wetlands and uplands. Samples were collected from black spruce upland and wetland positions to explore the distribution patterns of cryptogams for later use in selecting a preliminary list of cryptogam species for further testing. The sampling locations within each site were selected on the basis of problematic wetland conditions identified by local delineators. These problematic conditions included sites where vascular plant species occurrences were nearly identical in uplands and wetlands and the differences were in the presence or absence of 
TABLE 1. Sampling site details from 2004.

\begin{tabular}{|c|c|c|c|c|}
\hline Site ID & $n$ & Date & GPS Coordinates & Location/Description \\
\hline $1 \mathrm{Ua}^{1}$ & 10 & 08/09/2004 & $64^{\circ} 49^{\prime} 35^{\prime \prime} \mathrm{N}, 147^{\circ} 45^{\prime} 31^{\prime \prime} \mathrm{W}$ & $\begin{array}{l}\text { Interior Alaska, Fairbanks, Davis Road } \\
\text { Betula papyrifera and Picea mariana forest with Equisetum pretense Ehrh., Rosa acicularis Lindl., } \\
\text { and Vaccinium L. spp. Mosses are rare, no lichens due to B. papyrifera litter. }\end{array}$ \\
\hline $1 \mathrm{Ub}^{1}$ & 10 & $08 / 10 / 2004$ & $65^{\circ} 9^{\prime} 23^{\prime \prime} \mathrm{N}, 147^{\circ} 29^{\prime} 21^{\prime \prime} \mathrm{W}$ & $\begin{array}{l}\text { Interior Alaska, Caribou-Poker Creeks Watershed } \\
\text { Mature P. mariana forest with Betula glandulosa Michx., Equisetum silvaticum L., Ledum } \\
\text { groenlandicum Oeder, Vaccinium spp., and a continuous lichen-moss carpet. Lichens are abundant. }\end{array}$ \\
\hline $1 \mathrm{~W}$ & 20 & $08 / 09 / 2004$ & $64^{\circ} 49^{\prime} 35^{\prime \prime} \mathrm{N}, 147^{\circ} 45^{\prime} 31^{\prime \prime} \mathrm{W}$ & $\begin{array}{l}\text { Interior Alaska, Fairbanks, Davis Road } \\
\text { Bog with sparse P. mariana forest with a mixture of Larix laricina (Du Roi) K. Koch, with Ledum } \\
\text { groenlandicum, Vaccinium spp., and a continuous moss-lichen carpet. }\end{array}$ \\
\hline $2 \mathrm{U}$ & 20 & $08 / 11 / 2004$ & $64^{\circ} 52^{\prime} 44^{\prime \prime} \mathrm{N}, 147^{\circ} 40^{\prime} 5^{\prime \prime} \mathrm{W}$ & $\begin{array}{l}\text { Interior Alaska, Farmers Loop Road } \\
\text { Thick P. mariana forest with Calamagrostis canadensis (Michx.) Beauv., Ledum groenlandicum, } \\
\text { Petasites frigidus (L.) Fries var. frigidus, Vaccinium spp., and a continuous moss-lichen carpet. } \\
\text { Lichens of Peltigera Willd. spp. in extensive patches. }\end{array}$ \\
\hline $2 \mathrm{~W}$ & 20 & $08 / 12 / 2004$ & $64^{\circ} 57^{\prime} 9^{\prime \prime} \mathrm{N}, 147^{\circ} 42^{\prime} 50^{\prime \prime} \mathrm{W}$ & $\begin{array}{l}\text { Interior Alaska, Goldstream Valley } \\
\text { Bog with sparse P. mariana forest with Equisetum scirpoides Michx., Ledum groenlandicum, } \\
\text { Petasites frigidus (L.) Fries, Vaccinium spp., and a continuous moss-lichen carpet. }\end{array}$ \\
\hline $3 \mathrm{U}$ & 20 & $08 / 25 / 2004$ & $64^{\circ} 42^{\prime} 12^{\prime \prime} \mathrm{N}, 148^{\circ} 18^{\prime} 56^{\prime \prime} \mathrm{W}$ & $\begin{array}{l}\text { Interior Alaska, Tanana River flood plain, Bonanza Creek Experimental Forest } \\
\text { Mesic, mature, rather open P. mariana forest with Equisetum pretense, E. scirpoides, Ledum } \\
\text { groenlandicum, Rosa acicularis, Vaccinium spp., and a continuous moss-lichen carpet. }\end{array}$ \\
\hline $3 \mathrm{~W}$ & 20 & $08 / 21 / 2004$ & $64^{\circ} 51^{\prime} 19^{\prime \prime} \mathrm{N}, 147^{\circ} 49^{\prime} 11^{\prime \prime} \mathrm{W}$ & $\begin{array}{l}\text { Interior Alaska, Tanana River flood plain, Bonanza Creek Experimental Forest } \\
\text { Bog with sparse P. mariana forest with Chamaedaphne calyculata (L.) Moench, Eriophorum } \\
\text { vaginatum L., Ledum L. spp., Rubus chamaemorus L., Vaccinium spp., and a continuous moss- } \\
\text { lichen carpet. }\end{array}$ \\
\hline $4 \mathrm{U}$ & 20 & $08 / 19 / 2005$ & $61^{\circ} 10^{\prime} 03^{\prime \prime} \mathrm{N}, 149^{\circ} 48^{\prime} 21^{\prime \prime} \mathrm{W}$ & $\begin{array}{l}\text { South-Central Alaska, Anchorage, Dowling Road Extension } \\
\text { Picea mariana mesic mature forest with Cornus canadensis L., Geocaulon lividum (Richards.) } \\
\text { Fern, Ledum groenlandicum, Vaccinium spp., and a continuous moss-lichen carpet. }\end{array}$ \\
\hline $4 \mathrm{~W}$ & 20 & $08 / 19 / 2005$ & $61^{\circ} 10^{\prime} 00^{\prime \prime} \mathrm{N}, 149^{\circ} 48^{\prime} 32^{\prime \prime} \mathrm{W}$ & $\begin{array}{l}\text { South-Central Alaska, Anchorage, Dowling Road Extension } \\
\text { Boggy, sparse P. mariana forest with Andromeda polifolia L., Betula nana L., Chamaedaphne } \\
\text { calyculata, Empetrum nigrum L., Ledum ssp., Rubus chamaemorus, Vaccinium spp., and a } \\
\text { continuous moss carpet. Lichens are sparse but Peltigera spp. produce extensive patches. }\end{array}$ \\
\hline $5 \mathrm{U}$ & 20 & $08 / 14 / 2005$ & $64^{\circ} 54^{\prime} 20^{\prime \prime} \mathrm{N}, 147^{\circ} 49^{\prime} 11^{\prime \prime} \mathrm{W}$ & $\begin{array}{l}\text { Interior Alaska, Fairbanks, Ballaine Lake } \\
\text { Picea glauca and P. mariana mesic mature forest with Equisetum arvense L., Ledum palustre L., } \\
\text { Vaccinium spp., and a continuous moss-lichen carpet. }\end{array}$ \\
\hline $5 \mathrm{~W}$ & 20 & $08 / 15 / 2005$ & $64^{\circ} 51^{\prime} 57^{\prime \prime} \mathrm{N}, 147^{\circ} 52^{\prime} 30^{\prime \prime} \mathrm{W}$ & $\begin{array}{l}\text { Interior Alaska, Fairbanks, Smith Lake } \\
\text { Bog with sparse } \text { P. mariana, B. glandulosa, Calamagrostis canadensis, Empetrum nigrum, } \\
\text { Eriophorum vaginatum, Ledum groenlandicum, Rubus chamaemorus, Vaccinium spp., and a } \\
\text { continuous moss (Sphagnum L.) carpet. Lichens are rare. }\end{array}$ \\
\hline
\end{tabular}

${ }^{1}$ The Upland 1 was split into two sampling sites.

hydric soils and hydrology indicators. At each of the 2004 sites, we sampled a series of ten $50 \times 50 \mathrm{~cm}$ plots for cryptogam species presence and abundance. The plots, located at fixed intervals along two $30 \mathrm{~m}$ transects, each included both wetland and upland parts of a site. At each of these 11 sites, vascular plants were recorded and their abundance estimated using percent areal cover. The plot sampling for cryptogam occurrence in 2004 did not distinguish between hummocks and hollows; however, this distinction was made in 2005 as part of our test to verify species fidelity. Standard wetland delineation data for the three-factor approach were recorded from the field sites for vascular plants, soils, and wetland hydrology. Within sites, data were used to confirm whether each plot should be considered an upland or a wetland plot.

The prevalence index (PI) method (Wentworth et al., 1988) was used to support the determination of hydrophytic vascular vegetation at all study sites as part of the process of determining whether sites were upland or wetland. A weighted average was computed using the plot-based PI method described in Wakeley and Lichvar (1997). This method combines species areal cover and wetland plant indicator statuses to determine hydrophytic vegetation dominance. When PI values are 3.0 or less, the vascular vegetation is considered hydrophytic (U.S. Army Corps of Engineers, 2006).

To test the fidelity of the cryptogam indicator in black spruce communities, detailed sampling in 2005 was limited to the hydrologically monitored site at Smith Lake. Vascular vegetation was sampled for a set of three $10 \times 10 \mathrm{~m}$ plots at each of three monitored landscape positions, determined as wetland, upland, and the wetland boundary, using the threefactor wetland delineation methods. The three plots at each landscape position were located near the monitoring instruments in the field so that cryptogam distributions could be compared to hydrologic conditions along the gradient from upland to wetland. Within each $10 \times 10 \mathrm{~m}^{2}$ vascular vegetation plot, a series of five paired sets of $25 \times 25 \mathrm{~cm}$ cryptogam subplots were sampled using areal cover estimates. Each paired sampling set included the top of a hummock and its adjacent hollow. Microtopographic positions were more subtle in the uplands, where any slight mounding was considered comparable to a hummock top and a nearby depression was considered comparable to a hollow.

The soils at the Smith Lake site were described by Ping (2005). Soils at the Smith Lake upland (Site 1) plots were 
determined to be a well-drained silt loam lacking any hydric soil indicators and dominated by colors including 10YR 3/4, $2.5 Y 5 / 4$, and 2.5Y 4/4 (Gretag-Macbeth, 2000) within the upper $40 \mathrm{~cm}$. The Smith Lake wetland (Site 4) had hydric soils classified as an Uptic Histoturbel, with colors ranging from $10 \mathrm{YR} 2 / 2$ to $10 \mathrm{YR} 3 / 2$ muck without any redoximorphic features. Soils at the Smith Lake wetland boundary (Site 3) were classified as a Typic Histoturbel, with colors ranging from $2.5 \mathrm{Y} 4 / 3$ in the upper $23 \mathrm{~cm}$ to $10 \mathrm{YR} 2 / 1$ from 23 to $37 \mathrm{~cm}$ in depth and without any redoximorphic features. Both the wetland and the wetland boundary met the National Resource Conservation Service hydric soil indicator A1 for histosols (Hurt et al., 2003).

Cryptogam species, including bryophytes, fungi, and lichenized fungi, were collected from all sites in 2004, field-described, photographed, preserved as herbarium "voucher" specimens, and curated into the University of Alaska Mycological Herbarium (fungal, lichen, and moss collections). Dry voucher specimens have been placed in various herbaria for further study as indicated (bryophytes -ADT, ALA; lichens - LE, ALA; fungi - ALA).

\section{Data Analysis}

All 2004 cryptogam data were summarized by species occurrences in wetlands and uplands in our attempt to determine their wetland frequency of occurrence. Wetland frequency was determined from the number of wetland occurrences divided by the total number of occurrences (upland + wetland). Wetland abundance by species was calculated by summing the wetland areal cover values and dividing by the total cover values from both upland and wetland occurrences. The wetland frequency and the total number of occurrences of each species were used to determine 95\% confidence intervals for wetland occurrence using a binomial distribution model appropriate for data expressed as percentages (Sokal and Rohlf, 1981; Snedecor and Cochran, 1989). The binomial confidence intervals for species occurring in 30 or more plots were calculated using an approximation with an adjustment for continuity (Snedecor and Cochran, 1989). For less common species that occurred in fewer than 30 plots, a mathematical table of intervals was required. The binomial confidence levels were obtained using the $95 \%$ confidence interval tables of Blyth and Still (1983).

Species selected for further field testing in 2005 were those that had higher abundance, frequency, and chance of occurring in a wetland. A cryptogam species is defined as having higher abundance and frequency if our 2004 field sampling indicated it has relative cover value and frequency of occurrence of $67 \%$ or more. This value is similar to an FACW rating used for wetland vascular plants (Reed, 1988). A species is defined as having a high confidence level if it has a binomial confidence interval of $50 \%$ or greater for occurrence in wetlands. To select the best 2004 candidate species for further testing, we then stacked these three values to determine the species with the highest potential fidelity to occurrence in wetlands (hereafter, this layering of statistical values is referred to as the study-specific Cryptogam Reliability Model, or CRM). Species meeting CRM criteria were further reviewed and compared to the literature (Slack et al., 1980; Vitt and Slack, 1984; Vitt et al., 1988; Gignac and Vitt, 1990; Gignac et al., 1991; Camill, 1999) to validate their selection prior to further testing.

The 2005 data for cryptogams, vascular species, and selected environmental variables were summarized using Non-metric MultiDimensional Scaling (NMDS) ordination. Species with low frequencies, species occurring in fewer than three subplots, and subplots with fewer than three species were dropped from the analysis. NMDS algorithms are specified in Kruskal (1964) and Mather (1976) and are considered the preferred method (Minchin, 1987). The NMDS ordination was calculated and plotted using the R statistical software (R Development Core Team, 2008) with the Vegan package using the function metaMDS with default settings and an addition of up to 500 random starting positions to reach the ideal NMDS ordination configuration. Species-level response curves were also constructed using these data. Rare species were down-weighted. The upland landscape position was double-weighted to give it a weight equal to that of the two wetland landscape positions. A CA ordination axis in CANOCO (ter Braak and Smilauer, 2004) was used to construct species response curves based on a three-parameter Gaussian distribution in CANODRAW (Smilauer, 2003).

Cryptogam indicator values were calculated for each subplot. Differences in these values were tested using the Kruskal-Wallis nonparametric one-way analysis of variance (ANOVA). Dunn's pair-wise test was applied to compare the cryptogam indicator values between landscape positions using SigmaStat (SYSTAT, 2004a). Means and standard errors were calculated in SigmaStat and plotted in SigmaPlot (SYSTAT, 2004b) to further describe the distribution of wetland cryptogam abundance values.

\section{RESULTS}

\section{Soil Hydrology}

For the 2005 Smith Lake sites, the hydrology data included the soil moisture percentages recorded hourly at sites 1 and 3 (upland and wetland boundary). At the Smith Lake upland (Site 1), the soil moisture at depths of $20 \mathrm{~cm}$ decreased after thawing and then had brief increases after rain, indicating non-saturated conditions (Fig. 2). At the Smith Lake wetland boundary (Site 3), constant soil moisture after thawing indicated that the soil was saturated at $35 \mathrm{~cm}$, the shallowest moisture reading recorded. The Smith Lake wetland (Site 4) met the hydrology criteria for wetlands by having soils saturated to the surface and free water in a pit within $30 \mathrm{~cm}$ of the surface. 

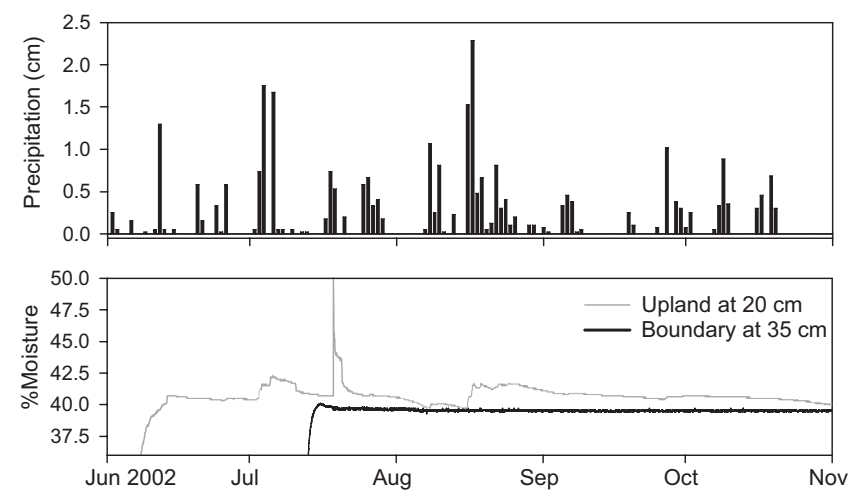

FIG. 2. Selected 2002 daily precipitation data from the University of Alaska Fairbanks College Observatory (National Climatic Data Center, 2005) and corresponding soil moisture recordings for the upland black spruce forest (Smith Lake Site 1) and the wetland boundary (Smith Lake Site 3) (V. Romanovsky, Permafrost Lab, Geophysical Institute, University of Alaska Fairbanks, pers. comm. 2005).

\section{Vascular and Cryptogam Responses}

A total of 86 cryptogam species were recorded in the 2004 study plots (Table 2). Of these, 56 taxa occurred in the upland plots and 76 taxa were observed in the wetland plots. Only five bryophyte species and five lichen species were restricted to uplands, while 19 bryophytes and 11 lichens were restricted to wetlands.

Overall, there were 43 bryophyte taxa and 43 lichen taxa recorded. Despite identical overall species numbers for lichens and bryophytes, the average number of taxa observed per plot was 3.81 for bryophytes and only 2.36 for lichens (Table 3). The average bryophyte cover of $67.4 \%$ was nearly five times greater than the average lichen cover of $14.4 \%$. Originally lichens were to be included in the analysis, but only eight lichen species were recorded in the 2005 field data, out of a total of 37 cryptogams. Of these eight lichen species, four were observed in both uplands and wetlands (Table 2), so we excluded lichens from further consideration because of their overlapping occurrences in both wetlands and uplands and their low cover values. Several wetland fungus species occurring outside plotted quadrats were observed during the study, but their occurrence was considered too ephemeral for their reliable use as hydrophytic vegetation indicators.

Species selected using the CRM (Fig. 3) were further evaluated and tested for wetland fidelity in 2005 (Table 4). The distribution of the pre-selected wetland bryophytes in 2005 (Table 4) corresponded with PI values along the upland-to-wetland gradient. The PI values ranged from 2.85 in the uplands (Site 1) to 2.68 at the boundary (Site 3) and 2.36 in the wetland (Site 4). These shifts in PI values represent two factors: species within the wetland proper tended to have mostly FACW and OBL ratings, which lowered their PI value. Also, the upland section of the black spruce stand, where hydric soils and hydrology indicators were lacking, had an increase in FAC, FACU, and UPL species that resulted in an increase of their PI values. The final 2005 list
TABLE 2. Number of bryophyte and lichen species from the 2004 and 2005 plot data.

\begin{tabular}{lccc}
\hline \hline & $\begin{array}{c}\text { Number of } \\
\text { Bryophyte } \\
\text { Species }\end{array}$ & $\begin{array}{c}\text { Number of } \\
\text { Lichen } \\
\text { Species }\end{array}$ & $\begin{array}{c}\text { Total Number of } \\
\text { Bryophyte \& Lichen } \\
\text { Species }\end{array}$ \\
\hline 2004 & & & \\
$\quad$ Upland Total & 24 & 32 & 56 \\
Wetland Total & 38 & 38 & 76 \\
Only Upland & 5 & 5 & 10 \\
Only Wetland & 19 & 11 & 30 \\
Total & 43 & 43 & 86 \\
2005 & & & \\
Upland Total & 7 & 6 & 13 \\
Wetland \& Boundary Total & 28 & 6 & 34 \\
Only Upland & 1 & 2 & 3 \\
Only Wetland \& Boundary & 22 & 2 & 24 \\
Total & 29 & 8 & 37 \\
\hline \hline
\end{tabular}

TABLE 3. Average numbers of bryophyte and lichen species per plot and average cover for upland, wetland, and all plots in 2004.

\begin{tabular}{lccc}
\hline \hline & Upland Plots & Wetland Plots & All Plots \\
\hline Bryophytes: & & & \\
$\quad$ Species per plot & $2.73 \pm 0.15$ & $4.89 \pm 0.20$ & $3.81 \pm 0.15$ \\
$\quad$ Cover (\%) & $68.3 \pm 3.1$ & $66.4 \pm 2.9$ & $67.4 \pm 2.1$ \\
Lichens: & & & \\
$\quad$ Species per plot & $2.07 \pm 0.24$ & $2.65 \pm 0.27$ & $2.36 \pm 0.18$ \\
$\quad$ Cover (\%) & $17.0 \pm 1.7$ & $11.8 \pm 1.6$ & $14.4 \pm 1.2$ \\
& & & \\
Bryophytes and lichens: & & & \\
$\quad$ Species per plot & $4.80 \pm 0.31$ & $7.54 \pm 0.33$ & $6.17 \pm 0.24$ \\
$\quad$ Cover (\%) & $85.3 \pm 3.3$ & $78.2 \pm 2.5$ & $81.7 \pm 2.1$ \\
& & & \\
\hline \hline
\end{tabular}

of wetland-specific bryophytes for problematic black spruce communities (Table 4) is associated with the lower wetland PI values that represent a community composed of vascular plant species that tend to have FACW and OBL ratings.

As summarized in an NMDS ordination (Fig. 4), 2005 cryptogam and vascular plant species from different landscape positions at the Smith Lake sites sorted into three groups. The upland group, mostly FACU understory vascular plants from the upland site in the black spruce blanket bog forest, clustered in the lower left portion of the axis with the lichen Cladonia furcata (Hudson) Schrader and mosses such as Hylocomium splendens (Hedw.) B.S.G. This group was associated with an increase in bryophyte cover and a higher PI value. The wetland hummock group, consisting of typical black spruce swamp OBL and FACW vascular plant species, clustered to the right of the upland group. Cryptogam species strongly associated with the wetland group were the moss Sanionia uncinata (Hedw.) Loeske, an epiphyte that was found in many plots, and the lichen Peltigera aphthosa (L.) Willd. Increases in understory vascular plant cover and hummock height were associated with the wetland hummock group. Located between these upland and wetland groups was the wetland boundary group, which contained vascular plants with wetland indicator status values ranging from OBL to FACW. The mosses Sphagnum warnstorfii Russ., S. squarrosum Crome, 


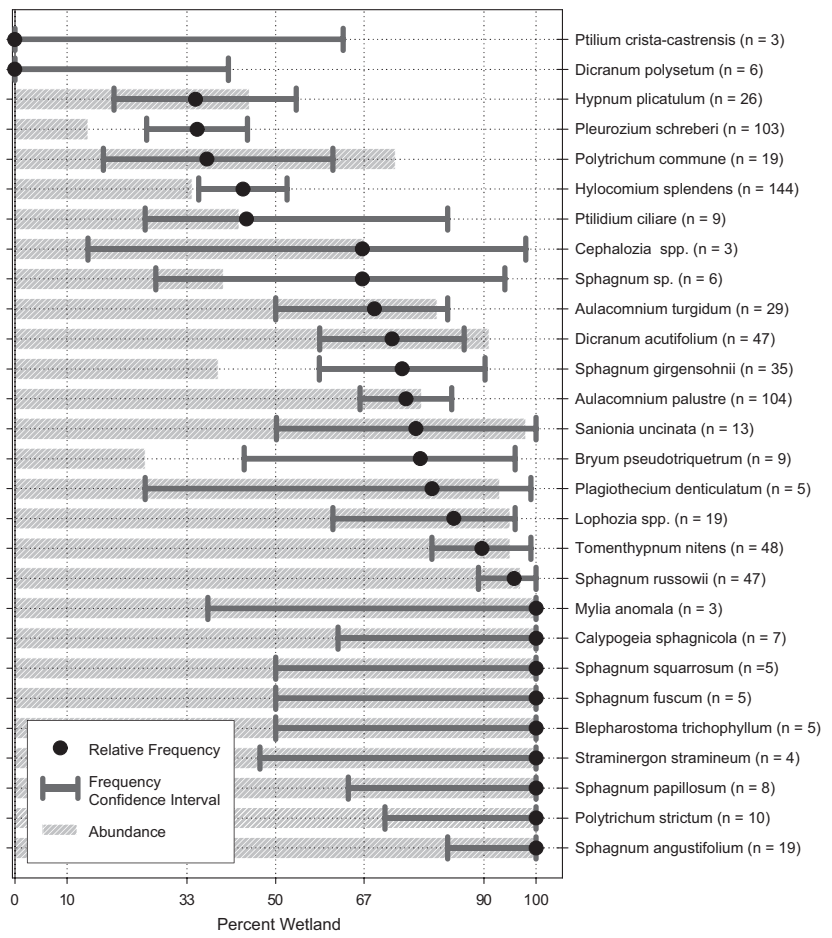

FIG. 3. Study-specific Cryptogam Reliability Model based on overlaying the frequency of occurrence, confidence intervals, and abundances (\% cover) in wetlands for bryophyte species included in the 2004 study.

and Tomenthypnum nitens (Hedw.) Loeske were some of the bryophytes strongly associated with this wetland boundary group.

Species response curves (Fig. 5) capture the communitywide distribution pattern for selected species that strongly sort along the upland-to-wetland gradient. The occurrence of tussock cottongrass (Eriophorum vaginatum L.), a FACW vascular species, begins at the wetland boundary, and the species increases in abundance farther into the wetland, where it is mostly confined to the tops of wetland hummocks (Figs. 4 and 5). The mosses Hylocomium splendens and Pleurozium schreberi (Brid.) Mitt. can co-occur on the wetland hummocks but become increasingly abundant on the upland black spruce forest floor. Other moss species, such as Tomenthypnum nitens, are mainly restricted to the wetland boundary and wetland hollows. Sphagnum russowii Warnst., which occurs farther into the wetland, is also mainly restricted to the wetland hollows.

There were distinct statistical differences in the relative abundances of wetland bryophytes between the six combinations of hummocks and hollows across the upland-towetland boundary and their wetland landscape position ( $p=<0.001$, Kruskal-Wallis Test). The 2005 test wetland bryophytes accounted for less than $5 \%$ of cover in the uplands (Fig. 6); however, a single plot contained a 30\% cover for Aulacomnium palustre (Hedw.) Schwaegr. This one isolated upland occurrence of $A$. palustre, a wetland cryptogam indicator species, was restricted to a deep hollow. The wetland bryophyte species dominated all but five of the wetland boundary hummocks. Of these, two were dominated by tussock cottongrass, two by the moss Hylocomium splendens, and one by the lichen Cladonia furcata, which limited the available habitat for test bryophyte species on these hummock tops. Inside the wetlands, test bryophyte species were widespread and common in the hollows, with fewer occurrences on the hummocks dominated by tussock cottongrass.

The upland site was correlated with increased bryophyte cover and PI value. The higher PI value indicates an increased presence of UPL and FACU understory species at the site. The upland vegetation also indicates that the soils have greater permeability and better ability to drain after precipitation events (Fig. 2). Hummocks were the least

TABLE 4. Bryphophytes selected in 2004 for further testing and final 2005 list of wetland bryophytes.

\begin{tabular}{|c|c|c|}
\hline Bryophyte Species & Selected for Testing & Final 2005 List \\
\hline Aulacomnium palustre (Hedw.) Schwaegr. & $\checkmark$ & $\checkmark$ \\
\hline Blepharostoma trichophyllum (L.) Dumort (hepatic) & $\checkmark$ & $\checkmark$ \\
\hline Bryum pseudotriquetrum (Hedw.) Gaertn., Meyer \& Scherb. & $\checkmark$ & \\
\hline Straminergon stramineum (Dicks. ex Brid.) Hedenas. & $\checkmark$ & $\checkmark$ \\
\hline Calypogeia sphagnicola (Arnell \& Persson) Warnst. \& Loeske (hepatic) & $\checkmark$ & $\checkmark$ \\
\hline Drepanocladus (C. Müll.) G. Roth spp. ${ }^{1}$ & $\checkmark$ & $\checkmark$ \\
\hline Meesia triquetra (L.) Aongstr. & $\checkmark$ & $\checkmark$ \\
\hline Meesia uliginosa Hedw. & $\checkmark$ & $\checkmark$ \\
\hline Mylia anomala (Hook.) S. Gray (hepatic) & $\checkmark$ & $\checkmark$ \\
\hline Pohlia proligera (Kindb.) Broth. & $\checkmark$ & $\checkmark$ \\
\hline Polytrichum commune Hedw. & $\checkmark$ & \\
\hline Polytrichum strictum Menzies ex Brid. & $\checkmark$ & $\checkmark$ \\
\hline Rhizomnium pseudopunctatum (Hedw.) T. Kop. & $\checkmark$ & \\
\hline Sphagnum angustifolium (Warnst.) C.E.O.Jens. & $\checkmark$ & $\boldsymbol{V}$ \\
\hline Sphagnum fuscum (Schimp.) Klinggr. & $\checkmark$ & $\checkmark$ \\
\hline Sphagnum papillosum Lindb. & $\checkmark$ & $\checkmark$ \\
\hline Sphagnum russowii Warnst. & $\checkmark$ & $\checkmark$ \\
\hline Sphagnum squarrosum Crome. & $\checkmark$ & $\checkmark$ \\
\hline Sphagnum warnstorfii Russ. & & $\checkmark$ \\
\hline Tomenthypnum nitens (Hedw.) Loeske & $\checkmark$ & $\checkmark$ \\
\hline
\end{tabular}

${ }^{1}$ Not including Warnstorfia, following the latest generic circumscriptions of Hedena. 


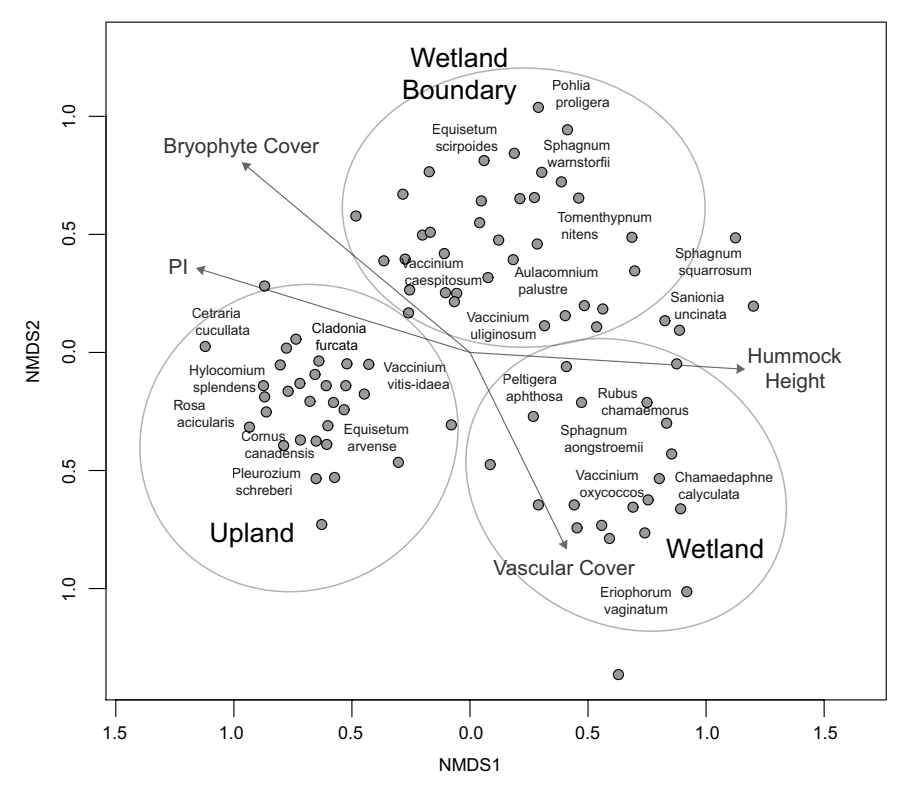

FIG. 4. Non-metric Multidimensional Scaling Analysis of the 2005 Smith Lake data. Clustered areas represent similar vegetation associations, both vascular and cryptogam, forming an upland black spruce blanket bog group, a wetland hummock group, and a wetland boundary group. (The positions of Latin names represent weighted scores for each species, and symbols represent site scores.)

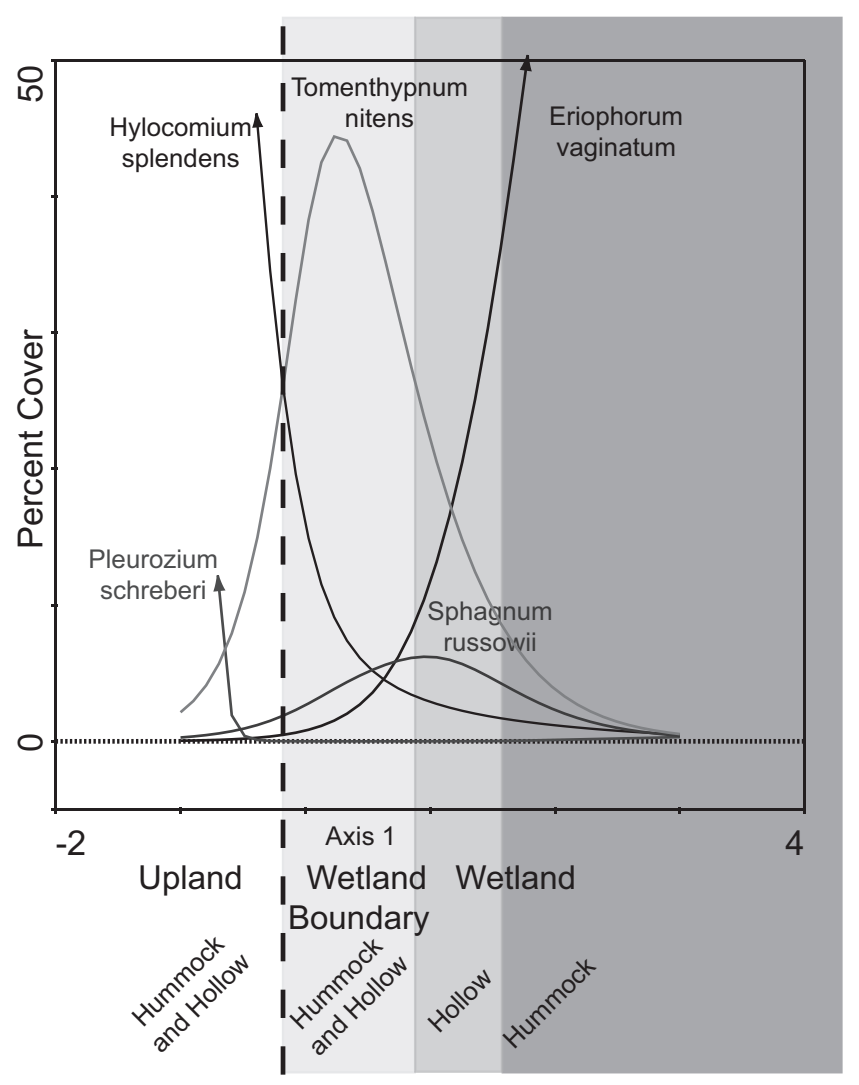

FIG. 5. Species response curves for five selected species, from the CA primary axis calculated in CANOCO (ter Braak and Smilauer, 2004).

developed in the upland forest; we recorded only a $15.7 \mathrm{~cm}$ average height from the hollow bottom to the hummock top in the upland.

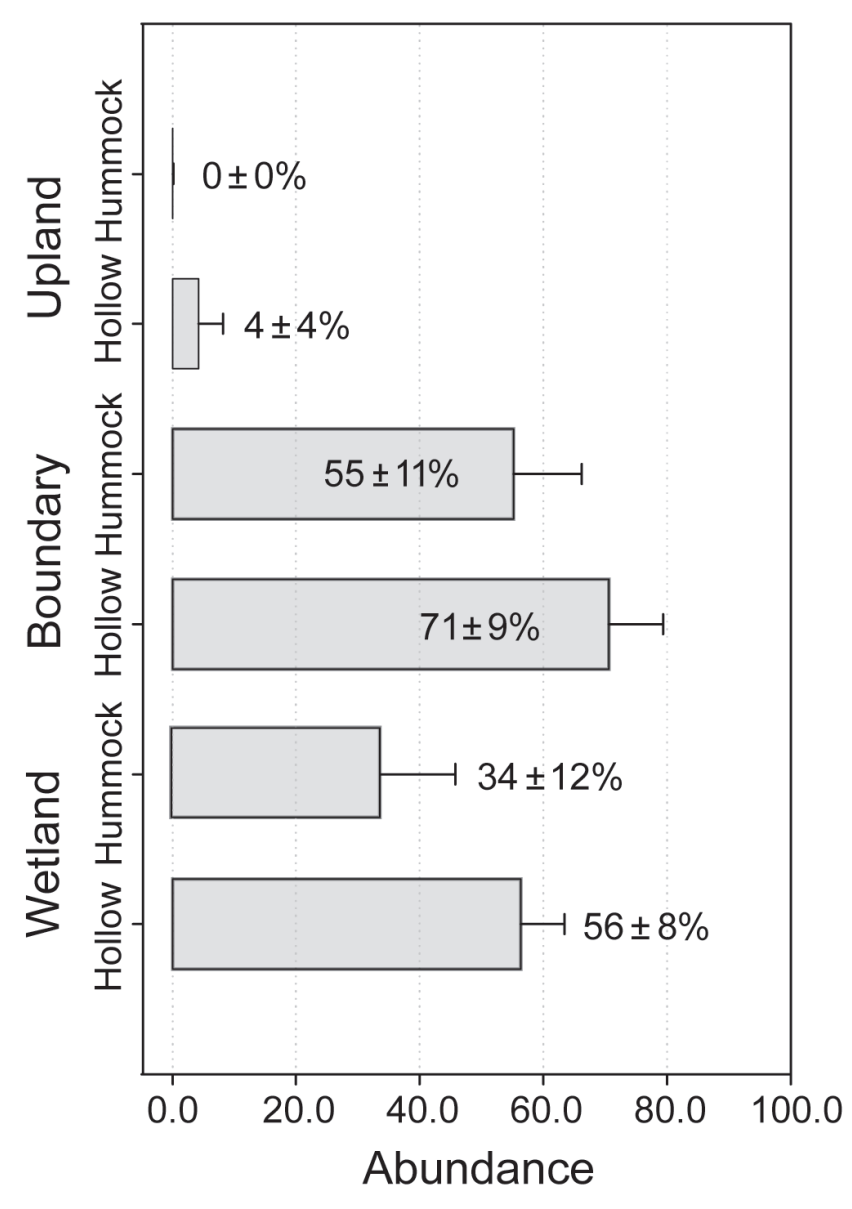

FIG. 6. Abundance of the 2005 test group of wetland bryophytes (Table 4) in hollow and hummock positions in Wetland, Boundary, and Upland areas.

In contrast, the Smith Lake wetland area had higher hummocks and greater vascular plant cover. In the black spruce swamp, the hummocks were well developed, with an average height of $32.8 \mathrm{~cm}$, and had distinct hollows surrounding them. The increase of vascular plants was dominated by tussock cottongrass (Eriophorum vaginatum). Eriophorum is well adapted to hummock surfaces and tops, and its dense growth habit limits the presence of cryptogam species. Hummock tops had a mixture of upland and wetland bryophyte species along with wetland vascular species. The wetland bryophytes were less frequent on hummocks within the wetland than on hummocks along the wetland boundary. This may be a result of differences in hummock height, relative depth to available water, and frequency of tussock cottongrass.

The species with the highest fidelity to wetlands were located in the hollows, regardless of whether they were at the base of hummocks, within the wetlands, or in the bottoms of the rolling moss hummocks along the wetland edge. The wetland boundary and wetland hollows were closely associated in the NMDS ordination axis (Fig. 4) and had the highest abundance and most similar wetland bryophyte species occurrences ( $p<0.05$, Fig. 6 ). At the wetland boundary, the hummocks and hollows were less distinct in height difference $(23.5 \mathrm{~cm})$ than those in the wetland proper. 
This lack of height distinction between hummocks and hollows indicates that both are closer to groundwater at this location and may explain the higher frequency of wetland bryophytes on hummocks and the high similarity of hummocks to wetland hollows (Figs. 4 and 5). The same separation of species distribution is observed in the ecological amplitude of several cryptogam and vascular plant species not only across the upland-to-wetland gradient, but in hummocks and hollows, as shown in the species response curve (Fig. 5). This distribution pattern is also expressed in wetland bryophyte occurrence. The wetland bryophytes being tested had abundances of $50 \%$ or more in $67 \%$ of plots in wetland hollows, but $80 \%$ of plots in wetland boundary hollows. We conclude that wetland bryophyte distribution patterns are associated with the distinction between hummocks and hollows, indicating that these two landforms should be sampled separately when using the cryptogam indicator.

\section{Strength of the Cryptogam Indicator}

A binomial frequency model was used to compute the probability of determining hydrophytic vegetation with our cryptogam indicator by combining data from the hydrologically monitored site for the $25 \times 25 \mathrm{~cm}$ plots. The frequency of hollow plots with more than $50 \%$ test-positive bryophytes was $7 \%$ in the upland, $67 \%$ in the wetland, and $80 \%$ in the wetland boundary. By combining three hollow subplots, the modeled chance of determining hydrophytic vegetation is $1.4 \%$ in the upland, $74 \%$ in the wetland, and $90 \%$ in the wetland boundary. These data suggest that a minimum of three representative cryptogam $25 \times 25 \mathrm{~cm}$ plots should be selected in hollows for accurately determining hydrophytic vegetation with fidelities ranging from $74 \%$ to $90 \%$.

\section{DISCUSSION}

Cryptogam species distributions associated with different black spruce community types have been reported elsewhere for boreal regions in North America (Robinson et al., 1989; Carleton, 1990; Gignac and Dale, 2005; Locky et al., 2005). These studies do not compare species occurrence in wetlands and uplands, which would be useful for wetland delineation purposes. Because wetland delineation boundaries frequently occur within the overall limits of a vegetation community, wetland cryptogam species lists based on associations with vascular plant community classification types lack the reliability needed for a wetland delineation cryptogam indicator. By surveying and analyzing occurrence data for cryptogam species in specific problematic black spruce communities, this study demonstrated a method for developing a list of wetland cryptogam species (Table 4) that can be used to delineate the extent of hydrophytic vegetation limits within certain black spruce problematic wetland vegetation types in Alaska. This approach is different from those used to determine vascular wetland plant indicator status elsewhere.
The vascular plants along the black spruce upland-towetland gradient at Smith Lake were almost entirely wetland species. Black spruce and several other widespread wetland species were frequent enough in the upland so that even that portion of the black spruce community still met the criteria for hydrophytic vegetation. Some of these widespread species include black spruce (FACW), Ledum groenlandicum Oeder (FACW), Vaccinium uliginosum L. (FAC), Salix planifolia Pursh (FACW), Betula glandulosa Michx. (FAC), and Calamagrostis canadensis (Michx.) Beauv. (FAC). This is not an unusual situation, and it has been reported on floodplains in Texas and the southern Appalachian region, where FAC species may not be a good indicator of wetland conditions in certain habitats where they are widespread and not associated with some combination of hydric soils or hydrology indicators (Wakeley, 1994; Dewey et al., 2006). But in Alaska, with its cold soils, which can influence infiltration rates (Ford and Bedford, 1987; Woo and Winter, 1993) and its low evapotranspiration rates, even some of the FACW species in black spruce communities have adapted to other, non-wetland habitat conditions, which reduces their reliability as indicators of hydrophytic vegetation conditions for delineation purposes.

\section{CONCLUSION}

Testing the fidelity of wetland cryptogam occurrences against hydrologically monitored positions at Smith Lake did not significantly change the initial pre-selected list from 2004 for the final bryophyte species list. The pre-selected list from 2004 identified 19 potential bryophyte species. After testing, three species were eliminated from consideration and one species was added, making the final list $84 \%$ similar to the initial 2004 list of wetland bryophyte species.

On the basis of results of testing the cryptogam indicator for problematic black spruce communities suggested by the Alaskan Vegetation Working Group, the cryptogam indicator is modified to:

$$
\text { Cryptogam Indicator }=\frac{\text { wetland bryophyte cover }}{\text { total bryophyte cover }} \times 100 \%
$$

where wetland bryophyte cover is the sum of the cover of selected wetland bryophytes and total bryophyte cover is the sum of all bryophyte cover. Hydrophytic vegetation is present if the cryptogam indicator is $50 \%$ or more.

This study was specific to cryptogams in black spruce wetlands in 2004 in the Anchorage and Fairbanks areas. It resulted in 2005 in the ranking of cryptogam species with the highest fidelity, which suggests an alternative approach that could be used for determining the limits of some problematic wetland communities, thus avoiding some problems inherent in assigning indicator ratings to vascular wetland plants. Selection of indicator species using the CRM approach is based on field data and analysis for a specific vegetation type in localized regions. This approach is a 
more reliable method for finding the hydrophytic boundary than the broader-based wetland plant indicator status rating system, which is based on anecdotal evidence and assigns ratings across a larger region. In other problematic wetland vegetation communities where vascular wetland plant indicator status does not match soil and hydrology indicators, a similar approach could be developed for specific subregions to determine what cryptogam species, or even which vascular species, could determine the hydrophytic portions of these communities.

\section{ACKNOWLEDGEMENTS}

Funding for the study was made possible by the Wetlands Regulatory Assistance Program (WRAP) of the U.S. Army Corps of Engineers (COE). We thank Mikhail P. Zhurbenko of the Komorov Botanical Institute, St. Petersburg, Russia, for his effort in identifying lichens in the field and laboratory during the 2004 portion of the study; Mary Plumb-Mentjes and Sheila Newman of the COE for site selections and field assistance during the study; and Dr. Chien-Lu Ping and Dr. Vladimir Romanovsky of the University of Alaska Fairbanks, who shared soil and hydrology data for the Smith Lake site in Fairbanks. We thank Sarah Gaines (COE) for her numerous comments on earlier versions of the manuscript, and the editor and two anonymous reviewers for their critical comments. And finally, we extend our thanks for their input and comments to the Alaskan Vegetation Working Group members who are part of the effort to subregionalize the COE wetland manual for the state, and who helped to develop the idea of using cryptogams for wetland delineation in Alaska.

\section{REFERENCES}

Alaskan Vegetation Working Group. 2005. Alaska Regional Corps of Engineers Wetland Delineation Manual Working Group. 11/30-12/1. Anchorage: AVWG.

Bedford, B.L., and Godwin, K.S. 2003. Fens of the United States: Distribution, characteristics, and scientific connection versus legal isolation. Wetlands 23:608-629.

Berglund, H., and Jonsson, B.G. 2001. Predictability of plant and fungus species richness of old-growth boreal forest islands. Journal of Vegetation Science 12:857-866.

Birks, H.J.B., Heegaard, E., Jonsgard, B., and Birks, H.H. 1998. Quantifying bryophyte-environment relationships. In: Ashton, N.W., Bates, J.W., and Duckett, J.G., eds. Bryology for the second century. London: British Bryological Society and W.S. Maney and Son Ltd. 305-319.

Blyth, C.R., and Still, H.A. 1983. Binomial confidence intervals. Journal of the American Statistical Association 78:108-116.

Camill, P. 1999. Patterns of boreal permafrost peatland vegetation across environmental gradients sensitive to climate warming. Canadian Journal of Botany 77:721-733.

Carleton, T.J. 1990. Variation in terricolous bryophyte and macrolichen vegetation along primary gradients in Canadian boreal forests. Journal of Vegetation Science 1:585-594.
Dewey, J.C., Schoenholtz, S.H., Shepard, J.P., and Messina, M.G. 2006. Issues related to wetland delineation of a Texas, USA bottomland hardwood forest. Wetlands 26:410-429.

Environmental Laboratory. 1987. Corps of Engineers wetlands delineation manual. Technical Report Y-87-1. Vicksburg, Mississippi: U.S. Army Engineer Waterways Experiment Station. http://el.erdc.usace.army.mil/elpubs/pdf/wlman87.pdf.

Ford, J., and Bedford, B.L. 1987. The hydrology of Alaskan wetlands, USA: A review. Arctic and Alpine Research 19: 209-229.

Gignac, L.D. 2001. Bryophytes as indicators of climate change. The Bryologist 104:410-420.

Gignac, L.D., and Dale, M.R. 2005. Effects of fragment size and habitat heterogeneity on cryptogam diversity in the low-boreal forest of western Canada. The Bryologist 108:50-66.

Gignac, L.D., and Vitt, D.H. 1990. Habitat limitations of Sphagnum along climatic, chemical and physical gradients in mires of western Canada. The Bryologist 93:7-22.

Gignac, L.D., Vitt, D.H., Zoltai, S.C., and Bayley, S.E. 1991. Bryophyte response surfaces along climatic, chemical, and physical gradients in peatlands of western Canada. Nova Hedwigia 53:27-71.

Gretag-Macbeth. 2000. Munsell ${ }^{\circledR}$ Color. New Windsor, New York: Gretag-Macbeth.

Hurt, G.W., Whited, P.M., and Pringle, R.F., eds. 2003. Field indicators of hydric soils in the United States, Version 5.01. Fort Worth, Texas: USDA Natural Resources Conservation Service in cooperation with the National Technical Committee for Hydric Soils.

Kershaw, K.A. 1995. Physiological ecology of lichens. Cambridge Studies in Ecology. New York: Cambridge University Press.

Kruskal, J. 1964. Nonmetric multidimensional scaling: A numerical method. Psychometrica 29:115-129.

Locky, D.A., Bayley, S.E., and Vitt, D.H. 2005. The vegetation ecology of black spruce swamps, fens, and bogs in southern boreal Manitoba, Canada. Wetlands 25(3):564-582.

Longton, R.E. 1997. The role of bryophytes and lichens in polar ecosystems. In: Woodin, S.J., and Marquiss, M., eds. Ecology of Arctic environments. Special Publication 13 of the British Ecological Society. Oxford: Blackwell Science Ltd. 69-96.

Mather, P. 1976. Computational methods of multivariate analysis in physical geography. London: J. Wiley \& Sons.

McCune, B., and Geiser, L. 1997. Macrolichens of the Pacific Northwest. Corvallis: Oregon State University Press.

Mills, S.E., and Macdonald, S.E. 2004. Predictors of moss and liverwort species diversity of microsites in conifer-dominated boreal forest. Journal of Vegetation Science 15:189-198.

Minchin, P. 1987. An evaluation of the relative robustness of techniques for ecological ordination. Vegetatio 69:89-107.

Muukkonen, P., Mäkipää, R., Laiho, R., Minkkinen, K., Vasander, H., and Finér, L. 2006. Relationship between biomass and percentage cover in understory vegetation of boreal coniferous forests. Silva Fennica 40:231-245.

National Climatic Data Center. 2005. Climatological observations, College Observatory, Fairbanks, Alaska (Daily recorded precipitation for June through November 2002). http://cdo. ncdc.noaa.gov/dly/DLY?stnid=20022302. 
Pharo, E.J., and Beattie, A.J. 1997. Bryophyte and lichen diversity: A comparative study. Australian Journal of Ecology 22: $151-162$.

Ping, C.-L. 2005. Guidebook to UAF NRM-F489/F689 Alaska soil geography field study: Permafrost dynamics and soil formation in Arctic and Subarctic Alaska. Palmer, Alaska: Palmer Research Station, Agricultural and Forestry Experiment Station, School of Natural Resources and Agricultural Sciences.

R Development Core Team. 2008. The R Project for statistical computing. Vienna, Austria: R Foundation for Statistical Computing. http://www.R-project.org.

Reed, P.B., Jr. 1988. National list of plant species that occur in wetlands: Alaska (Region A). Biological Report 88(26.11). Washington, D.C.: U.S. Department of the Interior, Fish and Wildlife Service.

Robinson, A.L., Vitt, D.H., and Timoney, K.P. 1989. Patterns of community structure and morphology of bryophytes and lichens relative to edaphic gradients in the sub-Arctic foresttundra of northwest Canada. The Bryologist 92:495-512.

Slack, N.G. 1988. The ecological importance of lichens and bryophytes. In: Nash, T.H., III, and Worth, V., eds. Lichens, bryophytes and air quality. Bibliotheca Lichenologica 30. $23-55$.

Slack, N.G., Vitt, D.H., and Horton, D.G. 1980. Vegetation gradients of minerotrophically rich fens in western Alberta. Canadian Journal of Botany 58:330-350.

Smilauer, P. 2003. CanoDraw for Windows, Version 4.12. Ithaca, New York: Microcomputer Power.

Snedecor, G.W., and Cochran, W.G. 1989. Statistical methods, 8th ed. Ames: Iowa State University Press.

Sokal, R.R., and Rohlf, F.J. 1981. Biometry: The principles and practice of statistics in biological research. San Francisco, California: W.H. Freeman and Company.

SYSTAT. 2004a. SigmaStat for Windows, Version 3.01.0. Richmond, California: SYSTAT Software Inc.

- 2004b. SigmaPlot for Windows, Version 8.02a. Richmond, California: SYSTAT Software Inc.

Ter Braak, C.J.F., and Smilauer, P. 2004. Canoco for Windows, Version 4.53. Ithaca, New York: Microcomputer Power.

Tiner, R.W. 1991. The concept of a hydrophyte for wetland identification. Bioscience 41:236-247.

- 2006. Lists of potential hydrophytes for the United States: A regional review and their use in wetland identification. Wetlands 26:624-634.
U.S. Army Corps of Engineers. 2006. Interim regional supplement to the Corps of Engineers wetland delineation manual: Alaska region. Wakeley, J.S., Lichvar, R.W., and Noble, C.V., eds. ERDC/EL TR-06-3. Vicksburg, Mississippi: U.S. Army Engineer Research and Development Center. http://el.erdc. usace.army.mil/wrap/pdf/trel06-3.pdf.

- 2009. National wetland plant list. https://maps.crrel.usace. army.mil/apex/f?p=393:111:72840403640675.

Vellak, K., Paal, J., and Liira, J. 2003. Diversity and distribution patterns of bryophytes and vascular plants in a boreal spruce forest. Silva Fennica 37:3-13.

Viereck, L.A., Dyrness, C.T., Van Cleve, K., and Foote, M.J. 1983. Vegetation, soils, and forest productivity in selected forest types in interior Alaska. Canadian Journal of Forest Research 13:703-720.

Vitt, D.H., and Slack, N.G. 1984. Niche diversification of Sphagnum relative to environmental factors in northern Minnesota peatlands. Canadian Journal of Botany 62:1409-1430.

Vitt, D.H., Marsh, J.E., and Bovey, R.B. 1988. A photographic field guide: Mosses, lichens and ferns of northwest North America. Edmonton, Alberta: Lone Pine Publishing.

Wakeley, J.S. 1994. Identification of wetlands in the southern Appalachian region and the certification of wetland delineators. Water, Air and Soil Pollution 77:217-226.

Wakeley, J.S., and Lichvar, R.W. 1997. Disagreements between plot-based prevalence indices and dominance ratios in evaluations of wetland vegetation. Wetlands 17:301-309.

Walker, M.D. 1995. Patterns and causes of Arctic plant community diversity. In: Chapin, F.S., III, and Körner, C., eds. Arctic and alpine biodiversity: Patterns, causes and ecosystem consequences. New York: Springer-Verlag. 3-20.

Wentworth, T.R., Johnson, G.P., and Kologiski, R.L. 1988. Designation of wetlands by weighted averages of vegetation data: A preliminary evaluation. Water Resources Bulletin 24:389-396.

Woo, M., and Winter, T.C. 1993. The role of permafrost and seasonal frost in the hydrology of northern wetlands in North America. Journal of Hydrology 141:5-31.

Zhu, L. 2004. Soil properties and forest stand characteristics along a toposequence of the Smith Lake area near Fairbanks, Alaska. MS thesis, University of Alaska Fairbanks, Fairbanks, Alaska. 